\title{
The Power Elite at 50: C. Wrights Mills' Political Sociology in Midlife Crisis
}

\author{
Steven P. Dandaneau
}

In 2000, Oxford University Press gave C. Wright Mills' classic statement in political sociology, The Power Elite (1956), a face-lift. Gone from its cover were the somber black-\&-white colors and clichéd Davy Crocket-like floating hats of yesteryear. The New Edition's fresh look is given by a cover wallpapered with photographs of The White House, Pentagon, and Wall Street, the hyper-ascendancy and anti-democratic integration of each sphere of national power therein symbolized described by Mills fifty years ago as having formed an emergent mid-century institution, a now-hidden, now-visible, American power elite. In a Wobbly lexicon that would become characteristically his own, Mills not only described a sociology of power in an increasingly bureaucratized United States, he also proceeded to identify the baleful, sobering consequences of this development, including particularly a world-historical irrationality of bureaucratic rationality that he believed stood back of the rapid, unchecked movement of the United Statestogether with its partner in nuclear brinkmanship, the Soviet Union-toward a perverse socio-political convergence and, quite possibly, finally, to each another's mutually assured destruction. The sympathetic reader might simply note that, in 1956, it was understandably difficult for the then-forty year-old Mills to see through the shadows cast back and forth between Max Weber and the coming Cuban Missile Crisis.

Or, one could go farther. In his 7 December 2005 Noble Lecture, British playwright Harold Pinter argues that, unlike the crimes of the Soviet Union, the postwar crimes of the United States "have only been superficially recorded, let alone documented, let alone acknowledged, let alone recognized as crimes at all." Mr. Pinter is outraged and apoplectic since, as he sees things, "the crimes of the United States have been systematic, constant, vicious, remorseless, but very few people have actually talked about them” (Pinter 2005). While Pinter never, of course, makes mention of C. Wright Mills, his characterization of the United States as every bit as undemocratic and menacing as the former Soviet Union is a bold statement perfectly consequent with both the spirit and the letter of Mills' nowfifty year-old political sociology. Since there is scarcely a prominent sociologist—nay, a leading social scientist of any stripe-who embodies these Millsian qualities, let the 75 year-old Harold Pinter stand-in for what C. Wright Mills might sound like were Mills celebrating his 90th birthday in August of 2006.

Perhaps not surprisingly, one does not find an updating of the sort called for by Pinter between the covers of Oxford's New Edition. Rather, the book's truly significant new addition is an Afterword by Alan Wolfe, most certainly among sociology's leading contemporary practitioners but also no particular fan of C. Wright Mills. Trained originally in political science and perhaps invited to provide his assessment partly for that reason, Wolfe's Afterword is aimed, as he writes, primarily at "[s]orting out what is helpful in Mills' book from what has become obsolete..." (2000: 366). It should be emphasized that Wolfe's reading of the book is not without appreciation for Mills' sociology, nor is his aim to discourage contemporary re-readings and continued critical appraisal of the work. Yet, it is too much to regard his as a sympathetic critique. As discussed at greater length below, Wolfe wishes to bisect Mills' descriptive sociology, which he regards as in some important respects skillfully elucidating the period with respect to which The Power Elite was written, from Mills' social criticism and proscriptions for political change, which Wolfe rejects as generally misguided and often mean-spirited, whether with respect to the situation fifty years ago or presently. [1]

For Wolfe, the world has changed. Capitalism that today operates on a global scale needs less its alliances with merely national elites, and long before the U.S. military lost its especially useful Cold War raison d'etre, its decline 
as a center of power was most prominently evident in its decreasing share of the national economic pie. Playing on the divergences between the Clinton and George W. Bush Administrations, Wolfe (himself a veteran of political involvement in the higher circles of the Democratic Party), also argues that the electoral politics that Mills imagined as a sideshow have in fact increased, not decreased, in political importance since Mills wrote in the mid-1950's. Given that he regards Mills' descriptive sociology of the period as the only aspect of the book meriting continued respectand this, only if gutted of its reliance on a theory of "mass society," which is central to Mills' argument but anathema to Wolfe-it is not surprising that Wolfe ultimately concludes that The Power Elite at fifty is effectively over-the-hill.

So, which is it? Has The Power Elite so aged that it is safe for use even in undergraduate courses as an example of a sociologically and politically "extreme" political sociology? Is it little more than a "classic," perhaps worth rereading if for no other reason than to pay heed to how mistaken a once-promising sociologist can be when, ignoring liberal-democratic American freedoms and the agency wielded even by everyday people (what Mills' ridicules as "The Great American Public"), theoretical arrogance led him to issue yet another failed attempts to predict the future? (1959: 298). Or, is The Power Elite at fifty a work as rarely understood as the "crimes of the United States," a prescient analysis that marks a breaking point in Mills' sociological oeuvre that divides his prior work from The Causes of World War Three (1958), Listen, Yankee! and a "Letter to the New Left" (1960a), and The Marxists (1962), that captures the significance of the political drama from Khrushchev's performance in the 20th Party Congress in 1956 to Dwight D. Eisenhower's Farewell Address to the Nation in 1961, that anticipates the onset of a long and as yet ending era of off-the-shelf politico-military criminal behavior (often termed "scandal"), from The Bay of Pigs, Dallas, the Tonkin Gulf Resolution, and on to the election of 1968, the general conduct of the Nixon Administrations and, of course, Watergate in particular, the election of 1980, the conduct of the Reagan Administrations and the Iran-Contra Affair in particular, the first Bush Administration and the war in Panama as well as the dubious entry of the United States into the first Gulf War in particular, the election of 2000, the response to the terrorist attacks of September 11, 2001, and the instigation of the military occupation of Afghanistan and a second Gulf War leading to the occupation of Iraq; all this as well as what is very probably not known about each and the events, one may reasonably presume, that exist in the in-between spaces of this fast-paced timeline? Does The Power Elite explain the very origin of these many postwar criminal acts and as yet verified criminal acts that Mr. Pinter believes have been wrought against numerous peoples (millions dead in Southeast Asia alone, among them), by the United States of America?

Since Wolfe's sympathetic unsympathetic assessment has the advantage not only of appearing perfectly reasonable but also of traveling with The Power Elite where ever it goes, this essay stresses a sympathetic, but also, as with Pinter's hypothesis, a stark-eyed and seemingly outlandish appraisal of the work. The Power Elite may be fifty, well-known and seemingly exhausted, but it bears to keep in mind that George Orwell's Nineteen Eighty-Four, its especially famed cousin across the pond, is an even more advanced 58 and arguably just as obscure as I suggest The Power Elite is from the point of view of today's dominant ideology.

\section{Last in a Trilogy or First Step into the Fire?}

Traditional interpretation locates The Power Elite as the third in a trilogy on the mid-century structure of power in the United States and in advanced industrial society generally. The best and most obvious reason for so doing is that Mills himself described the book this way. In a 1951 letter to Philip Vaudrin, editor at Knopf, Mills writes the following postscript:

P.S. Just made a decision the other day. After I finish Character and Social Structure, which Gerth and I have been on since God knows when (Weber, I guess) Harcourt has it; and [after I finish] the Metropolitan Weekend (no contract), I am going to do a book called The Rich or The Upper Class or something like that. This will complete my trilogy: The New Men of Power (lower classes), White Collar (middle class), then upper stuff... (Mills and Mills 2000, editorial addition in original: 155).

Thus, there is nothing evidently askew with Mills' putative biographer, Irving Louis Horowitz, discussing The Power Elite under the title of "Trinity of Power" (1983: 256-281). First discussed privately in 1951, Mills notes in The Power Elite's acknowledgements that "[a] first draft of the materials was completed while in residence as a visitor at Brandeis University during the spring of 1953...” (1956: 383). A long time in coming and rooted primarily in Weber: 
that is the usual shorthand context given for interpreting the significance of Mills' most famous book.

There is no question that Mills' sociology and his self-understanding as a sociologist were in this period both greatly influenced by the looming figure of Max Weber. As Mills notes even in the passage just quoted, at the time he first began to plan The Power Elite he had been working with Hans Gerth on Weber "since god knows when," which is to say, since roughly 1939, when Mills arrived at the University of Wisconsin to pursue doctoral work in sociology and soon thereafter began a productive if also notorious collaboration with Gerth, the brilliant German émigré widely acknowledged for his considerable knowledge of Weber as well as, even more impressively, that to which Weber addressed himself (see Oakes and Vidich 1999). Indeed, the analysis in The Power Elite most certainly owes more to Weber than any other social thinker, for Mills' study of the "command posts" of power stands or falls with a Weberian understanding of modern bureaucratization. This is the case even though, ironically, Weber's name never appears in the text and even though Weber's monumental oeuvre is cited only once, this, tangentially and via reference to From Max Weber: Essays in Sociology (1946), translated and edited by Gerth and Mills.

But it is not the presence or absence of Weber's acknowledged or unacknowledged influence that is presently at issue. Mills had already, in White Collar, for example, explicitly acknowledged Weber's paramount, and Marx's nearequal, importance for Mills' own "general perspective" (1951: 357). Rather, the more pointed question concerns of which aspect of Weber's multifaceted sociology predominates in the text, and of the increasing relative influence of Marx, various Marxian theorists, and Frankfurt School theorists in particular, evident in its pages. For in The Power Elite, we see Mills doing something much more than merely rounding-out his trilogy on power with a value-neutral analysis of increasingly hierarchal bureaucratic organizations that concentrate and integrate power at their apexes, something akin to an application of Roberto Michels' "iron law of oligarchy" to the mid-century American national political scene (see Michels 1996). [2] Instead, we see Mills much more closely following the example of the Max Weber who was riveted by immediate political concerns, often personally engaged in Weimar politics, and more than willing to issue damning judgments on the hypocrisy and irresponsibility of governing elites and the culture, or lack thereof, they countenanced, encouraged, and very often fed off. As Weber was to the Kaiser, so was Mills to Eisenhower and, later, Kennedy (see Diggins 1999).

But it goes beyond style and bravado. More than at any time prior in his career, The Power Elite finds Mills wedding historical and political concerns - a focus on the process of history-making generally and the prospects for democratic history-making and the making of modern democracy in particular-to structural analyses. This is where Wolfe especially wants off the Good Ship Mills. As noted above, for Wolfe, The Power Elite "is really two books," one that is sociological analysis written in a "somewhat clinical language" and "driven by data" and "extensive original research," the other written using a "language of outrage" in which Mills presents himself as though as a "biblical prophet" predicting "doom" and "harshly denouncing 'the second rate mind' and the 'ponderously spoken platitude” (2000: 377-78). But this two-books reading begs the integrity of Mills' argument. What if Mills' structural analysis and his historicizing and, indeed, radical social criticism cannot be separated from one another without violating the work's raison d'etre? What if accepting Mills' structural analysis of the concentration and integration of power leads quite logically and necessarily to an analysis of those who wield that power and the historically specific projects to which they apply its use? Weber did this, as did Marx. So, too, beginning most clearly with The Power Elite, did C. Wright Mills.

This is why it is curious and unfortunate that Wolfe's assessment makes no mention of the Cuban Missile Crisis, for that such a thing was not only possible, but probable, is arguably the great animating force running throughout The Power Elite and spilling out into all, or very nearly all, of Mills' subsequent publications. It is this fact that interpreters of Mills generally either miss or under play. Perhaps it is that they give Mills' own "trilogy" self-assessment too much weight. Having established himself as a tenured member of the discipline's leading faculty, the mid-1950's saw Mills set his aim on what for him would be a higher ambition, not higher for personal rewards (although Oakes and Vidich would disagree), but higher in the sense of being historically relevant, that is to say, influential on a scale that shaped history-making, which meant, as an American, simply on a national scale. International respectability and alliances were edifying and useful and, alas, nonessential. Due to the specifics of modern historical social development, influencing the American course of history was tantamount to influencing the total course of human history.

Thus, The Power Elite not only addresses the concentration of power, it is itself an attempt to exercise a form of power. In it, Mills moves from being an excellent sociologist to being an excellent sociologist who is also a skilled political writer. [3] He hoped to be so skilled, in fact, that his interventions directly into public life—as he called them, in an act of self-deprecation, his "preachings" — would bypass the academy and be accepted to some meaningful 
degree by publics. Only through their democratic actions would there result tangible, meaningful historical difference in the direction of social change. Not so much hubris as the result of dismay and alarm (or perhaps a mixture of all three), Mills sought to engage what he called the mindless "main drift" of a bureaucratically determined historymaking set-up, which he saw (and not him alone, of course) as tending toward the worldwide spread of bureaucratic unfreedom and permanent war among competing undemocratic national elites. This historical situation was, as it were, historically unprecedented and grave. The first-half of the twentieth century featured two world wars and the use of atomic bombs followed by the advent and deployment of thermonuclear weapon systems. The threat of continued worldwide military conflict and large-scale nuclear war was real. To avert an apocalyptic war by restoring the realistic hope of reason and freedom playing a predominant role in the conduct of human affairs, this is what motivated The Power Elite and its author.

Understood as such, we can see that The Power Elite has little to do with perpetually answering the question, "Who Rules America?" (Domhoff 2005 [1967]), nor does it make sense that in its wake there were inspired innumerable studies of the increasing integration of corporate and government power and various and sundry subsequent insults this has caused to "the public interest" (for a review of the "corporate liberalism" literature in political sociology, see Cornoy 1984). Indeed, the emergence generally of a so-called "critical sociology" that is manifestly inspired by Mills is largely out of sync, not only with a basic grasp of the factual situation that Mills addresses in The Power Elite, but also with all of his "preachings" following thereafter. Mills was not interested in establishing a Millsian branch of sociology that set up its own self-marginalizing journals and professional societies and that used Paul Lazarfeld's preferred methods of research to study topics of interest to left-liberal social critics. Not only The Power Elite, but The Sociological Imagination (1959), Images of Man (1960b), and other more clearly "sociological" subsequent works make this point abundantly clear, or so one might have imagined.

Mills' interest, which he shared with sociology's founders, was the totality of modern and, increasingly, postmodern society. The Power Elite announces an interest in direct participation in the making of human history in the hope of directly affecting its outcome. This is the only reasonable understanding of his self-described "plain Marxism" and the only interpretive framework that makes sense of his dedication to helping to form a "new left." Horowitz therefore exaggerates only slightly when he notes that:

Mills's ...defense of 'plain Marxism' and his growingly strident attack on 'liberalism as a dead end,' must each be seen as an ultimate rejection of Weber...(1983: 186).

As the Frankfurt School demonstrated better than any other group of social theorists, it is readily possible to incorporate the considerable fruits of Weber's penetrating analyses of the "administered world" into a critical theory of society. This is how The Power Elite should be read, as marking Mills' emergence as a pragmatist-trained and distinctively American critical theorist of society. [4]

Merely four years later, Mills would find himself riding around Cuba in a Jeep with Fidel Castro while President John F. Kennedy was forced to explain to a visiting French journalist critical of U.S. policy toward Cuba, "I'm not some sociologist, I'm President of the United States" (Beschloss 1991: 658).

\section{Playing in Peoria, Port Huron, and the Pentagon}

It is one kind of irony that The Power Elite would emerge in a society in which many of its leading social analysts, Daniel Bell prominent among them, were actively declaring "the end of ideology" (see Bell 2000 [1962], Mills 1960). Yet it was a far more disconcerting irony that the ideology of the end of ideology was in fact gaining empirical credence by its institutionalization and enculturation in a mid-century "American way of life." The contemporary value of The Power Elite is very much tied to its prescient analysis of the process through which mass society was reproducing itself out of itself. The emergent social totality was one in which "the cultural apparatus" and its celebrity-producing star-system played an ever-greater role in defining the meaning of collective human experience, such that the taken-for-granted "culture" increasingly acquired a commercial and centrally administered quality. Ultimately, as the distance from autonomous, spontaneous, and local culture increased, "culture" became sufficiently ethereal in its cynical self-understanding to accept with little fuss its unabashed use as ideological support for seemingly any political expediency. The preponderance of myriad mass broadcast circuses led Mills to be among the first to pronounce the onset of a "fourth epoch," a "post-modern society" defined by the eclipse of 
autonomous individuality in possession of reason and freedom as operative cultural realities. In place of modernity, Mills feared that "cheerful robots" would strut on the stage of strip mall and sidewalk sale, the mirror image of "the higher immorality" in a society polarized between obscene concentrations of power and equally obscene forms of powerlessness (see Mills 1959, Ryan 1976, Dandaneau 2001).

This sort of descriptive rhetoric drives critics like Alan Wolfe crazy. As Wolfe writes:

As he brings his book to an end, Mills adopts a term once strongly identified with conservative political theorists. Appalled by the spread of democracy, conservative European writers proclaimed the twentieth century as the age of 'mass society.'

'The United States is not altogether a mass society, Mills wrote, but he then went on to write as if it were.

Mills had become so persuaded of the power of the power elite that he seemed to have lost all hope that the American people could find themselves and put a stop to the abuses he detected (2000: 379-380).

In these passages, Wolfe accuses Mills of antidemocratic allegiances, disingenuous writing, and self-delusion. Wolfe also regards Mills as arrogant and irresponsible as well as, in the end, anti-American.

That sense of engagement with America once sparked writers like Ralph Waldo Emerson and Walt Whitman to hold their country up to a higher standard. All too often Mills does not share their generous sense of American life and writes instead as cantankerous critic, sour in his anger, rejectionist in his views of the world around him (2000:380).

But Wolfe may underestimate how amenable Mills' legacy has been to the type of "affirmative culture" analyzed by Herbert Marcuse (1969 [1937]). As noted previously, most of Mills' putative followers are usually content with "critical sociology" and making award of the C. Wright Mills Award. [5] Certainly, Oxford's New Edition of The Power Elite, featuring Wolfe's damning appraisal of at least half of the book (not to mention the character of its author), does little to promote Mills' point of view in Peoria.

In Mills' defense, however, he does in fact write that "the United States is not altogether a mass society"; indeed, his overriding point is succinctly and clearly rendered as follows: "The bottom of this society is politically fragmented, and even as a passive fact, increasingly powerless: at the bottom there is emerging a mass society" (1956: 324, emphasis added). As a critical theorist, Mills aimed to counteract what he saw as a rapidly developing tendency toward corruption of democratic life by clearly identifying the emerging, alarming threat to its vitality: in a word, bureaucratization. Mills wrote The Power Elite so that it would be accessible to what ever remained of a reading public (not unlike much of the best of Wolfe's sociology), in the hope that his clarion call might contribute to efforts to forestall and reverse what he regarded as an obviously perverse and, needless to say, anti-American social tendency. This is hardly the behavior of a social critic who is rejecting communication with the world around him, his own society included. For this charge to stick to the wall, it would be necessary to explain why Mills poured his heart into The Causes of World War Three (1958), which sold over 100,000 copies, Listen, Yankee! (1960), which sold over 400,000, and such overtly political tracts as "Letter to the New Left" (1960a), which rejects political complacency among even the disheartened and marginal defenders of the ideals of social equality and participatory self-government. Horowtiz seems much closer to the mark: Mills was "An American Utopian," the subtitle of his biography, although certainly a more radical critic than Emerson, Whitman, or Wolfe. Perhaps it is that the critic of "the American Celebration" doesn't play as well as assigned reading in the canon of The PBS-sanctioned American Experience. Given, however, Mills' increasing use as the stuff of 50's nostalgia (see Halberstam 1994), no one in today's postmodern society should be surprised if Mills were required reading Peoria Central High School. Politically speaking, it wouldn't matter.

When not ensnared in nostalgia for "New York in the 50's" (see Wakefield 1999), Mills is sometimes appears as the figment of Port Huron and the 60's student movement collective (mass) memory. Whereas Mills was more concerned with what Comrade Khrushchev was saying about Comrade Stalin's crimes to the 20th Party Congress than with what Jack Kerouac was writing as he drove across America, Mills' insistent reach for the big picture, what Dan Wakefield remembers him as calling the act of "taking it big" (see 2000; Dandaneau 2001), endeared him to many among an emerging, generationally construed New Left. Primarily via the influence of Tom Hayden, who wrote an M.A. Thesis on Mills and who was principal author of “The Port Huron Statement” (2005 [1962]), Mills, and in particular, the Mills of The Power Elite, is understood as a seminal influence on student activism in the U.S. in the 1960's (see also Gitlin 2005). Even though deceased prematurely in 1962 at only age 46, Mills' writings lived on whether as part of American Radical Thought: The Libertarian Tradition (1970), or, in the title of Jamison and 
Eyerman's oft-cited retrospective, simply as Seeds of the Sixties (1994).

So, the kids were reading Mills and, later, Marcuse, who himself went out of his way in the preface to OneDimensional Man (1964) to acknowledge Mills' importance. [6] But what of the power elite themselves? Did they read Mills?

Other than with respect to Fidel Castro, who is said to have held discussions on The Power Elite whilst hold-up in Sierra Maestra, we may never know how far Mills' analysis of power elites penetrated their elite, guarded inner sanctums. There is no evidence, for example, that President Eisenhower or his speech writers drew even indirectly from Mills in composing Eisenhower's nonetheless pointed farewell critique of "the military-industrial complex." And even though Mills traveled to the Soviet Union and Poland, there is no evidence that his often-confrontational engagements with communist officials in either country led them, much less their superiors and their superiors still further up, to any sort of intellectual or political engagement with his ideas. And while Mills is likely to have been on President Kennedy's mind in the passage quoted above in interaction with French journalist, Jean Daniel, there is no evidence that Kennedy actually read Listen, Yankee!, such as he later claimed, famously, with respect to Michael Harrington's The Other America.

But it is not therefore irrelevant that Eisenhower would issue an analysis so clearly consonant with Mills'. In fact, it would be hard to imagine a figure more clearly embodying the characteristics of Mills' prototypical member of the power elite than Dwight David Eisenhower himself, former Supreme Allied Commander for Europe, President of Columbia University, and two-term President of the United States. That Ike sat down to tell The Great American People to beware "the total influence-economic, political, even spiritual" of "the military-industrial complex" ought to weigh, it seems, rather heavily in our appraisal of The Power Elite. That he did so firm in the conviction that " $[\mathrm{t}]$ he potential for the disastrous rise of misplaced power exists and will persist," should be counted among the most ringing endorsements any thesis has ever, anywhere, received.

We must never let the weight of this combination endanger our liberties or democratic processes. We should take nothing for granted. Only an alert and knowledgeable citizenry can compel the proper meshing of the huge industrial and military machinery of defense with our peaceful methods and goals, so that security and liberty may prosper together (1961).

So the general-turned-president and political leader of the conservative party chose to take leave of office, on national television, in prime time. Perhaps this individual member of the power elite was not as "mindless" as Mills feared commonplace, but, sadly, his particular act of self-criticism had as little consequence as Mills' structural analysis of bureaucratic mindlessness predicted.

\section{The Best Evidence}

It is one thing to discuss particular responses to the work, quite another to come full-face with the workings of what the book is about. That is, academics[7] can spill ink all day and night on the text, The Power Elite, but the far more important subject is that which the book addresses: actually existing power elites.

Here, social science—positivist or critical or what have you—quickly runs up against an especially delicate and confounding conundrum: a social science thesis that, if correct, cannot be sufficiently supported by evidence. If Mills' analysis were essentially if not entirely accurate, then the very power elite he had identified would, by definition, enjoy sufficient power to more or less prevent exposure of its most undemocratic acts. In other words, if Mills is right that the United States is governed by an unelected, unaccountable, increasingly integrated and, not unimportantly, increasingly self-conscious power elite, then these self-same individuals would presumably recognize the danger to the legitimacy of the system of power in which they occupy the top positions posed by exposure to social science and, from there, to a reading public. Some, like Eisenhower, might go public with their concerns. But the majority of such an elite would no doubt equate "national security" and the security of the power elite in toto, thus establishing safeguards and methods designed to buffer elite decision-makers from public scrutiny and subsequent accountability.

A social science of political power-in this society, at this point in its historical development—would then, presumably, be left looking for what ever skimpy evidence of such machinations is available. Not an exactly quixotic endeavor, however. After all, history is replete with cases-in-point of the fact that even the exceedingly powerful make mistakes. And as human beings who are operating in human institutions, even the so-called power elite must necessarily leave traces, and perhaps a great deal more than that, of its workings. Finally, it bears to recall that 
power-especially a claim to total power-is never simply given; elite structure, like all social structure, is in constant need of reproduction.

The empirically minded social scientist might thus query: Are new legal and administrative institutions of government being created as substitutes for existing democratic seats of power? Are ideological justifications for politically expedient uses of authority being created and propounded as necessary and just? Are undemocratic methods for the control of information, election of leaders, repression of dissent, and support of vested interests being devised? Social science might also, of course, benefit from occasional or not-so-occasional slip-ups in the prosecution of various elite-directed projects. The blanket term "scandal" describes these, but it also obfuscates their significance. The sociologist is interested in scandals rooted in structural arrangements, that is, systematically produced scandal, not those resulting from idiosyncratic or merely personal failings. Reasonable inferences might follow from the latter concerning the institutional structure of power as such, whereas the former distract attraction form the latter and potentially confuse the would-be citizen-analyst.

Mills notes that the growth of the power elite, with respect to which "the military ascendancy" is essential, dates from "Pearl Harbor" (see 1956: 198). The fear aroused by a military attack against the United States and the immediate national resolve to enter wholesale into the second world war of the century was wedded to an already vastly enlarged New Deal state bureaucracy, the result being a "greatly speeded up" increase in the concentration and integration of national power (1956: 274). Less often discussed is the fact that numerous observers at the time and, presently, on the basis of historical documents newly available to researchers, many more, are left incredulous by the fact that the U.S. Navy broke the Japanese military code only some 100-odd days after the attack on Pearl Harbor. This code-breaking achievement is celebrated because it was essential to the decisive U.S. naval victory in the Battle of Midway in June, 1942, a mere seven months after Pearl Harbor. And while school children are taught that Pearl Harbor was a horrible defeat of U.S. forces, the truth is that the fleet attacked that day was less its only strategically valuable vessels, three aircraft carriers (each on separate missions), and that therefore the result of the attack, which led to the U.S. entry into the war in both theatres of conflict, was a disaster for Imperial Japan's long-term war aims [8].

Fast-forward from December, 1941, to the first days of the Truman Administration. The three-term president is dead. Just as the fourth-term commences, the now-former Vice President must be informed by the Chief of the Joint Chiefs of Staff not only of the existence of the Manhattan Project, but of the need to use its fruits vis-à-vis as fresh targets in Japan. This same Harry S. Truman, never really an insider to the power elite even during his presidency, would sign into law the National Security Act of 1948, creating institutions whose very purpose was to provide the executive and the military-intelligence branch of government freedom from democratic constraint and accountability. He would also engage the United States in what was effectively a spatially and technologically contained version of World War III with China (Eastasia) and the Soviet Union (Eurasia) on the Korean Peninsula, and find it necessary a short time later to remove a glaringly insubordinate general from command of what amounted to U.S. protectorates, colonies, and Legions in Asia. For this, Truman, Mrs. Roosevelt, and a good many of their fellow Democrats were denounced by the hysterical anticommunist right wing-followers of MacArthur and McCarthy—as highly suspect if not thoroughly un-American. In this world, Eisenhower and the Administration most directly analyzed by Mills between the pages of The Power Elite thus came to power.

Under Eisenhower (and, when he was ill, Vice President Nixon as acting president), the United States developed, deployed, and continuously expanded a capacity to exterminate human life worldwide via thermonuclear weapons (a fact both so common and so profound that it is worth pausing for a moment to ponder). Against the backdrop of atomic and hydrogen bomb tests and non-stop construction of missile silos, nuclear submarines, and intercontinental bombers, the simultaneous on-going covert political and military intervention in myriad ostensibly sovereign nationstates' internal political affairs, including use of violence against heads of state, must have seemed minor. Where subversion was not possible, the Eisenhower Administration did not hesitate to use espionage, such as regular U-2 flyovers of the Soviet Union, including, for example, on May Day, 1960.

Here we arrive at the onset of what T.V. historian Michael Beschloss (1991) calls "the crisis years," 19601963. Given its position as following The Power Elite but not so distant as to allow for intervening structural change, this brief but highly eventful historical period may provide the best evidence for Mills' thesis in The Power Elite. The furor that erupted upon the downing of Francis Gary Power's U-2 spy plane ended years of calculated rapprochement pursued by Eisenhower. There would be no trip by the Eisenhower family to the Soviet Union mirroring Khrushchev's early tour of the United States. Less than one year later, a new President would refuse to risk 
world war by authorizing full-scale military support for what became known as "the Bay of Pigs" invasion, a CIA-led effort by Cuban exiles to overthrow the revolutionary government of Cuba. During this period, President Kennedy, a former Navy Ensign, further undermined his never-good credibility with the military-industrial establishment by threatening action against U.S. Steel (using a national television broadcast, no less), and by pursuing policies that threatened the favorable extra-normal profits that accrued regularly to other key oligopolistic industries, oil among them. From the point of view of the elite members of the committed anticommunist right wing, President Kennedy's womanizing and risky self-medication, the suspect electioneering in Illinois and elsewhere in 1960, not to mention his tentative support for the Civil Rights Movement, must have been viewed as relatively less grievous than his support for a nuclear test ban treaty with the Soviet Union, his inaction during the Bay of Pigs and Cuban Missile Crisis, and his pointed and, seemingly, growing hesitancy concerning the prospect of full-scale U.S. military involvement in Southeast Asia. The American University Commencement Address, the so-called Peace Speech, of June, 1963, would have been nothing but the coup de grace in a fundamentally disturbing trend.

But before conciliatory, even philosophical, speeches about peaceful coexistence between elites Soviet and American, there would first be a nuclear standoff the likes of which the world has never seen before or since. If 1960 gave us the U-2 incident and 1961 the Bay of Pigs, 1962 featured the crisis par excellence, the Cuban Missile Crisis. As historians have now shown, the U.S. military chiefs wanted nothing but war with Cuba, and, by extension, war with the Soviet Union. They also wanted nothing but full-scale war in Vietnam and its immediate environs. While these facts are now well known, it is cause for extra pause and reflection. Mills' thesis pointed to an increasingly integrated elite composed primarily of the national political directorate (namely, the president and his inner circle, particular in matters of national security), the military elite (namely, the joint chiefs and their immediate subordinates), and the corporate elite (namely, the CEO's and Board Chairs and their immediate lieutenants among the top 50 or 100 multinational corporations). President Kennedy showed that merely the scion of a rich and politically involved New England family, using personal wealth and the power of celebrity to his advantage, could obtain the nation's highest elected office. Still, he did not mesh comfortably with the existing elites, especially those exercising power outside the direct reach of his authority. Imagine the gulf in sensibility between Kennedy and his Air Force Chief of Staff, General Curtis LeMay of Columbus, Ohio, who cut his teeth overseeing the firebombing of Tokyo while JFK was merely commanding PT-109. No disinterested military bureaucrat, LeMay, it is often overlooked, would serve as George Wallace's Vice Presidential running mate in 1968. But neither MacArthur nor, later, LeMay, crossed the Rubicon (at least not openly), and Kennedy's personal stand against many of his many senior advisors, including military advisors, LeMay prominent among them, meant that war with Cuba would be relegated to a costly and ultimately ridiculous Operation Mongoose and a still-on-going merciless trade embargo.

In these same years, Mills himself, as did other sociologists, acquired FBI surveillance (see Keen 1999, Dandaneau 2001). The internal civil liberties of American citizens had long been violated on a scale so massive as even today to defy comprehension by most people. Intelligence agencies spied on American citizens and harassed legitimate political organizations. Unsuspecting soldiers, whole cities and communities as well as specific minority groups, such as African-Americans and disabled children, were subjected to life-threatening radiation testing, sterilization, and other forms of heinous, Nazi-like biomedical experimentation (see Department of Energy c. 1994). Intelligence agencies engaged in proactive counterintelligence operations against groups identified secretly as threats to the vaguely understood "national security," including the FBI's now-infamous COINTELLPRO's that began in 1956 and continued until 1971, when they were exposed.

Mills' FBI files are comparatively pedestrian to that which would be, for example, eventually amassed in response to Malcolm X and Dr. Martin Luther King, Jr. Most of the 200-odd pages are of little historical interest. The files do reveal, however, that Mills received a death threat and that he was moved to purchase a pistol for self-protection. Unfortunately, significant passages of these files are redacted, and we still do not know today the identity of the halfa-dozen or so informants who reported on Mills' whereabouts and activities. Likewise, the CIA, for its part, claims to have no substantive files on Mills, which is typical of CIA responsiveness to Freedom of Information Act requests. One might expect Central Intelligence Agency to have monitored an American citizen who traveled more than once to the Soviet Union, to Poland, and who worked with Fidel Castro and his government, not to mention who lectured widely as a severe critic, not just of U.S. foreign policy generally, but with respect to the most sensitive point in the pressure vice known as the Cold War: Cuba.

Mills died in March of 1962. He suffered a second major heart attack. The first occurred in 1960 just prior to a scheduled national television debate on NBC on the subject of U.S. policy toward Cuba. While Mills was left in a 
coma for days, the American people were left with Congressman Charles O. Porter of Oregon filling Mills' shoes vis-à-vis Adolf A. Berle. Mills' death was marked by a Washington Post and Times Herald obituary and Castro sent a wreath to adorn Mills' grave. Seven months later, the Cuban Missile Crisis erupted.

One can only speculate how Mills would have approached that crisis. Likewise, one can only speculate as to how the native Texan and 1934 Dallas Technical High School graduate might have analyzed the events of November, 1963. Surely, though, Mills' view of President Kennedy, which was very dim from the outset of his Administration, might have improved considerably as a result of Kennedy's June, 1963, Commencement Address at American University, which Kennedy delivered six months before his assassination and which is perhaps second only to Eisenhower's Farewell as free copy for the veracity of The Power Elite. Kennedy told the graduates that day:

\begin{abstract}
I have...chosen this time and place to discuss a topic on which ignorance too often abounds and the truth too rarely perceived. And that is the most important topic on earth: peace. What kind of peace do I mean and what kind of peace do we seek? Not a Pax Americana enforced on the world by American weapons of war. Not the peace of the grave or the security of the slave. I am talking about genuine peace....
\end{abstract}

I speak of peace because of the new face of war. Total war makes no sense in an age where great powers can maintain large and relatively invulnerable nuclear forces and refuse to surrender without resort to those forces....

Today the expenditures of billons of dollars every year on weapons acquired for the purpose of making sure we never need them is essential to the keeping of peace. But surely the acquisition of such idle stockpiles-which can only destroy and never create-is not the only, much less the most efficient, means of assuring peace....

Calling repeatedly for American self-critique and the eventual abolition of Cold War mentalities and institutions, Kennedy staked his presidency, and his reelection, on the avoidance of what he called a "collective death-wish for the world."

From the point of view of assessing The Power Elite, the key point is to underscore that the events heretofore discussed did not occur upon debate in Congress or after national public discussion. In fact, little of the history that has occupied the last several paragraphs was even known until relatively recently, to well-informed citizens or otherwise, most of whom might have been simply dumbstruck or more likely obstinately incredulous were she or he have somehow learned of it as it was unfolding: e.g., "What do you mean, "President Johnson disavows the Warren Commission Report?!" [9] That the American people are largely left with a pack of failed Congressional investigations and sensationalist Hollywood movies in response to these deadly sobering events—events which also led to the downfall of Khrushchev, not insignificantly, and the ascendancy in the Soviet Union of a comparably illiberal governing elite-is itself an indication of the undemocratic structure of the American polis extending forward in time from the early 1960's.

Thus, as we now know, the Gulf of Tokin Resolution, an act of Congress giving carte blanche to the Johnson Administration in its zeal to escalate the war in Vietnam, was based on wholly erroneous intelligence. And, as we now know, the Nixon Campaign's efforts to forestall a peaceful conclusion of the War in Vietnam in 1968 helped secure the former Vice President's election to the presidency that just barely eluded him in 1960, this, whereas previously only the murder of his principal political foe, Senator Robert F. Kennedy, was known to be the key event opening the door to Nixon's rehabilitation as a national political force and his subsequent policies that included liberal domestic programs as well as the prosecution of a secret, unauthorized war in Cambodia and the murder of democratically elected heads of state and counterrevolutionary insurgency elsewhere in the world.

Rightly or wrongly, the Watergate Scandal, of course, is the mother of all scandals in American political history, but its basic structure as a de facto coup d'etat is rarely acknowledged. Mostly rooted in illegal attempts to shape the election of 1972 (in which Governor Wallace was severely wounded in an assassination attempt), Watergate provides an unusual glimpse into a gapping whole in the fabric of systemic elite obfuscation. Top members of the national intelligence establishment, including but not limited to Mark Felt, purposively leaked information that they hoped would be fatally damaging to President Nixon's legitimacy. And, it was. A failed, law-breaking, and psychologically fragile president was thus forced from office by covert actions of the elite establishment surrounding him. That the Supreme Court demanded subpoenaed evidence and that Congress prepared articles of impeachment does not vitiate the fact that neither branch of federal government would have had knowledge of Nixon's crimes, such as we do know of them, without the instigation of an illicit process of delegitimation from secretive actors within government who lacked legal authority for their actions.

This concerns only what is acknowledged and known. But, in the case of Watergate, we also know at least one 
thing precisely that we do not know, which is rare. We know that someone deemed it necessary to erase 18.5 minutes of presidential conversation from the infamous Watergate Tapes. The National Archive in Washington D.C. suggests, in their display of the actual tape-recorder, that the erased conversation probably concerned the break-in at the Watergate offices of the Democratic National Committee Chairperson. Whether this speculation is accurate or not is not likely ever to be known, although Nixon's Chief of Staff, H.R. Haldeman, the person with whom President Nixon was conversing during time in which the gap in the tape recording appears, noted in his posthumously published memoir that, when President Nixon curiously referred to the Bay of Pigs invasion, which he often did, Nixon, speculated Haldeman, was actually referring to the assassination of President John F. Kennedy (Haldeman 1978, 1994).

One imagines a tired reader. A reader who does not now want to be reminded again of the flimsy evidence suggesting, as in 1968, a similar campaign-led effort to alter the outcome of the election in 1980, or the armsfor-hostages and later arms-for-money deals associated with President Reagan's senior National Security Council advisors and his Administration's illegal war in Nicaragua (see Sick 1991). Furthermore, one imagines that President G. H. W. Bush's stunning and incredibly brutal seizure of the President of Panama by means of military invasion, as depicted, for example, in the Academy Award-winning documentary, Panama Deception, is relatively familiar to most readers, as would be Ambassador April Glaspie's utterance before reporters made famous by H. Ross Perot in his on-air, mid-debate assault on George H. W. Bush: "Obviously," said the U.S. Ambassador to Iraq, "I didn't think, and nobody else did, that he Iraqis were going to take all of Kuwait," referring to informal U.S. communications with Saddam Hussein prior to Iraq's 1991 invasion of Kuwait. And certainly, readers of this publication need not be reminded of the election of 2000 or events subsequent to the terrorist attacks of 2001, in which jets were crashed or were intended to crash into symbols of each of Mills' elite triad.

Even if the details of this or that "scandal" are doubtful and perhaps more the product of paranoid fantasy than established historical fact, the crucial question remains, does Mills' The Power Elite, now 50 years dated, anticipate the structures and processes standing back of the undemocratic concentrations of coordinated power that have been used on a regular basis to prosecute acts which stand in violation of U.S. and international law as well as that contradict the principles of American democracy which are the putative sources of legitimacy for the American state? Yes or no?

The 60's social movements helped to check some of the most blatant abuses of the power elite. Were it not for the activists who burglarized the FBI in 1971, well before the Church Committee was impaneled, the world would not, for example, know anything about COINTELLPRO (see Cunningham 1994). And, certainly, the anti-war movement was a significant factor in the tragic, tortured withdrawal — but still, the withdrawal—of U.S. forces from Vietnam. Yet, qualifications aside, even a simple listing of key (known) events in U.S. political history since 1956 suggests, apart from rare but heroic moments of countervailing struggle, a more or less uninterrupted continuation of (apparent) usurpations. Indeed, it is reasonable to speculate that, in the absence of a fundamental collapse in its structure, the power elite's worst "crimes," as Pinter suggests as the proper vocabulary, are probably not yet known nor likely ever to be sufficiently documented, at least sufficiently documented so as to meet the test of a tape-recorded confession, the so-called "smoking gun" test, which is perhaps the most ironic product of Watergate. Eisenhower's Farewell Address to the Nation, Kennedy's American University Address, H. R. Haldeman's memoirs—and testimony from abroad, particularly in the wake of the collapse of the Soviet Union and its Warsaw Pact satellite regimes-are as close to a smoking gun as Mills and his way of analyzing power are likely to get.

\section{Is Mills Winston Smith or Emmanuel Goldstein?}

George Orwell's Nineteen Eighty-Four is arguably the most discussed and most familiar single work in twentiethcentury English language literature, yet it is, nonetheless, rarely well understood (see Dandaneau and Falcone 1998[10]). In the usual reading, Winston Smith is the book's hero, O’Brien its villain. But Smith, a middle-level functionary, is as self-deluded as the Proles he disparages as often as glorifies. They horde the petty material goods of life while he, Winston, hordes shaving razors and a sense of his own historical importance; they consume beer and pornography ("prole feed"), while he covets Victory Gin and his diary; Smith denounces the Proles' ignorance while he takes pleasure in expertly rewriting history, his work at the Ministry of Truth. Vis-à-vis the Inner Party, Smith is similarly self-deluded. O'Brien entraps Smith with deceit and then proceeds to torture him, but Smith cannot 
sever his affection for power and ends up loving Big Brother despite it all. Ostensibly critical of Doublethink, Smith practices it with acuity.

Likewise, the usual interpretation of Goldstein is satisfied with comparing the character with the historical figure of Leon Trotsky (the pen name of Lev Davidovich Bronstein). Goldstein's text-within-a-text, The Theory and Practice of Oligarchical Collectivism, is therefore understood as a metaphor for exiled "truth" used effectively by totalitarianism as a means of policing its ideological borders. Failing to understand the totality of his situation, Smith is easily lured into O'Brien's trap. Had he been a lesser thinker-say, one not fascinated by the equation $2+2$ $=4$-he might have enjoyed a similar fate but via means of a failed hyper-conformity, as in the case of Parsons, or in a failed rebellion of the flesh, as in the case of Julia. But Winston Smith was an intellectual workman of the Outer Party, and as such, required Goldstein upon which to exercise his soul during regular "Two Minutes Hate."

The chief sociological problematic of Orwell's classic, as in Mills', is the anticipation of the ideological consequences of power in a total society or, the same thing, in a thoroughly undemocratic social order. The present discussion of The Power Elite might therefore profitably conclude with an assessment that asks if Mills was as self-deluded as Winston Smith or whether The Power Elite is as penetrating as Trotsky's The Revolution Betrayed (for the United States is, or was, a revolutionary society as much as was the Soviet Union)? Further complicating the question is the evidence provided by Orwell's own extraordinary ideological reception: despite his book's unparalleled popularity, it has been so regularly distorted by Cold War struggles that its core reflexivity, the auto-critique set in Oceania of the bourgeois intellectual's self-delusion, is scarcely recognized and certainly not much talked about. Harold Pinter, who lives in Airstrip One, is an exception to this general rule.

Perhaps in this last observation, we unexpectedly have our answer. No one doubts, as in Wolfe's analysis, that global capitalism is a revolutionizing force driven from within by its inherent growth requirements, and that postmodern culture speeds up the production of commercialized lives and spreads itself thin to all four corners of the globe. Analysts who discuss the details of either, as did Mills, are bound to have their work dated by that which they are talking about. Likewise, everyday electoral politics, even in the United States, do matter because not all significant political problems are of world-historical significance, and nostalgia is what it is what it is (repeat ad nauseam).

But the advent of every new generation means that power, even in a total society, must struggle to reproduce itself, lest a new generation become caught-up in history's unfinished and unfalsified business and ask too many impertinent questions. To wit: Is it not perfectly telling that, as Soviet freighters ferried nuclear weapons to the tiny island of Cuba, C. Wright Mills' intellectual contemporaries gathered at his memorial service on New York City's Morningside Heights to murmur on his having lost his mind? Or, that leading sociologists even today would gloss the structurally determined possibility (dare I say, probability), that the United States would again be engaged in potentially disastrous war on demonstrably false pretexts, its people and resources again hitched to grandiose acts of criminality at home and abroad? Indeed, is it not perfectly clear, as Mr. Pinter might say, that the United States most desperately needs a stiff dose of perestroika and glasnost?

\section{Endnotes}

1. In the mid-1980's, Wolfe moved away from an earlier and perhaps stronger sympathy with the sort of radical political sensibilities and commitments embodied by C. Wright Mills. While there is nothing in itself suspect about his shift in political thinking, it is, however, ironic that the Society for the Study of Social Problems awarded the C. Wright Mills Award to Wolfe's Whose Keeper?: Social Science and Moral Obligation (1989), which announces this shift.

2. Unlike Weber's work, Michels is not even once discussed or cited, even though Mosca and Pareto are referenced on several occasions. See discussion of the Germanic versus the Franco-Italian influences on Mills' theory of power in Horowitz (1983), especially pages
180-182. Mills does, however, provide an excerpt from Michels on the "iron law of oligarchy" in his Images of Man.

3. "Political writer" is Mills' own 1953 autobiographical description of his ambition and telos. See Dandaneau 2001: 80-84, especially 82 .

4. Mills' pragmatist metatheoretical proclivities are not the only aspect of his work that distinguishes it as "American." There is of course the influence of Veblen (see Tilman 1984, 2004). And there is also the fact that Mills --unlike Horkheimer and Adorno, for example, but more in line with Marcuse-- had a developing interest in what he termed "the hungry nation bloc" (see 
Dandaneau 2001: 74-76). Listen, Yankee! , his time spent lecturing in Mexico, and his largely unfinished magnum opus, Comparative Sociology, suggest the increasing importance of Mills' movement away from a strictly Anglo-European sociology, which is characteristic of American as opposed to European critical theorists.

5. An illustrious award counting among its recipients dozens of excellent works and excellent sociologists. See http://www.sssp1.org/index.cfm/m/24/pageId/47 for a list of past recipients.

6. The connections between Mills and the principal members of the so-called Frankfurt School were several but always fleeting. A not exhaustive list of points of contact includes: a) via Gerth, who once himself enjoyed the support of Frankfurt's Institute for Social Research (see Jay 1996, but note also the letter from Mills to Gerth probably in 1952, in which Mills writes: "The Frankfurt bunch are not going to let me (and I doubt you) into their inner circle: i.e., give us enough money to do what we want to do: shuttle between here and there and write what we want about both places" (Mills and Mills 2000: 168); b) at Columbia University, where the Institute for Social Research was famously in residence during the Second World War and where Franz Neumann would later remain as a member of the faculty; c) during this time, Mills provided an anonymous editorial review (held as part of the C. Wright Mills Papers at the University of Texas-Austin) of the manuscript for Horkheimer's Eclipse of Reason $(2005)$; d) in a 1954 occasional piece in the Saturday Review in which Mills notes the importance of several aspects of Frankfurt School work, he writes: "I know of no better way to become acquainted with this endeavor [that is, "the classical sociological endeavor"] in a high form of modern expression than to read the periodical, Studies in Philosophy and Social Science, published by The Institute of Social Research. Unfortunately, it is available only in the morgues of university libraries, and to the great loss of American social studies, several of the Institute's leading members, among them Max Horkheimer and Theodore [sic] Adorno, have returned to Germany" (in Horowitz 1963: 572); e) in 1957 or 1958, Mills lectured at "Frankfurt University" (see 1958: 173, acknowledgements); f) Mills cites a study by the Institute's Otto Kirchheimer in The Power Elite (1956: 407); f) Mills quotes Horkheimer in The Sociological Imagination (1959: 122-123) and sought input from Marcuse on early drafts of the manuscript (C. Wright Mills Papers); g) Leo Lowenthal is photographed with Mills at Mills' New York apartment "in the late 1940's" (see Mills and Mills 2000) and acknowledged as a source, as is Marcuse's Reason and Revolution, for White Collar (1951: 357).

7. Students interested in the strictly academic reception of The Power Elite should consult Domhoff and Ballard (1968), Horowitz (1983), and Aronowitz (2004). These provide useful secondary discussion as well as easy access to the influential criticisms leveled against Mills by Talcott Parsons, Daniel Bell, Seymour Martin Lipset, Robert Lynd, and other disciplinary luminaries, as well as sympathetic criticisms from such figures as Paul Sweezy and Tom Bottomore. The present essay does not treat The Power Elite as an academic contribution to social theory per se but as a contribution to the critical theory of society. The perspective taken is consistent with the functions of "radical history" long ago set out by Howard Zinn and that include: a) highlighting extreme historical conditions, b) political expose, c) culture critique, d) recovery of utopian possibilities, and e) critique of failed historical ambitions (see 1990: $35-55)$.

8. My intention in this essay is not to provide extensive historical references, as though symbolizing a wellfounded scholarly historical terrain. In any case, such references would be either unnecessary or inadequate, depending on the reader's point of view. Still, one might profitably review such diverse scholarly sources as Gaddis (2005), Errol Morris' 2003 Academy Awardwinning documentary film, The Fog of War, and Kellner (2005). An example of the popular and largely sensationalistic literature surrounding these events of recent history is Stinnett (2001) on Pearl Harbor and Lifton (1992) on the assassination of President Kennedy. The existence of "true crime" reportage and its "conspiracy theorist" devotees stigmatizes, fairly as well unfairly, all efforts to address the dubious political history of the past fifty years. Works by the likes of Gary Wills (1968), Norman Mailer (1995), and James Carroll (2006) help to counter the main tendency, but the main tendency remains nonetheless (see Dandaneau 2001).

9. Actually, LBJ did so repeatedly, privately while still in office and publicly, in an interview with Walter Cronkite, after leaving office.

10. This thesis is primarily Falcone's, whose original statement is her M.A. Thesis in philosophy, "Dystopian Elements in Richard Rorty's Liberal Utopia," accepted at Michigan State University.

\section{References}

Aronowitz, Stanley, ed. 2004. C. Wright Mills. Three-Volume Set. Thousand Oaks, CA: Sage.

Bell, Daniel. 2000 [1962]. The End of Ideology. Cambridge: Harvard University Press.

Beschloss, Michael. 1991. The Crisis Years: Kennedy and Khrushchev, 1960-1963. New York: Edward Burlingame Books.
Carroll, James. 2006. House of War: The Pentagon and the Disastrous Rise of American Power. Boston: Houghton Mifflin.

Cornoy, Martin. 1984. The State and Political Theory. Princeton: Princeton University Press. 
Cunningham, David. 1994. There's Something Happening Here: The New Left, The Klan, and FBI Counterintelligence. Berkeley: University of California Press.

Dandaneau, Steven P. 2001. Taking It Big: Developing Sociological Consciousness in Postmodern Times. Thousand Oaks, CA: Pine Forge Press.

Dandaneau, Steven P. and Falcone, Maude. 1998. A Wrong Life: Studies in Lifeworld-Grounded Critical Theory. Stamford, CN: JAI Press.

Department of Energy, Office of Human Radiation Experiments (March, 1994). http://www.eh.doe.gov/ohre/index.html.

Domhoff, G. William. 2005 [1967]. Who Rules America? Fifth Edition. New McGraw-Hill.

Domhoff, G. W. and Ballard, H.B., eds. 1968. C. Wright Mills and The Power Elite. Boston: Beacon Press.

Eisenhower, Dwight David. "Farewell Address to the Nation." 17 January 1961. http://www.americanrhetoric.com/speeches/ dwightdeisenhowerfarewell.html.

Gaddis, John Lewis. 2005. The Cold War: A New History. London: Penguin.

Gitlin, Todd. 2005. The Intellectuals and the Flag. New York: Columbia University Press.

Halberstam, David. 1994. The Fifties. New York: Ballantine.

Haldeman, H. R. 1994. The Haldeman Diaries. Introduction and Afterword by Stephen E. Ambrose. New York: Putnam.

Haldeman, H. R. and Dimona, Joseph. 1978. The Ends of Power. New York: Dell.

Hayden, Tom. 2005 [1962]. The Port Huron Statement. New York: Thunder's Mouth Press.

Horkheimer, Max. 2005 [1947]. Eclipse of Reason. New York: Continuum.

Horowitz, Irving Louis. 1983. C. Wright Mills: An American Utopian. New York: The Free Press.

Jamison, Andrew and Eyerman, Ron. 1995. Seeds of the Sixties. Berkeley: University of California Press.

Jay, Martin. 1996 [1973]. The Dialectical Imagination. Berkeley: University of California Press.

Keen, Mike Forrest. 1999. Stalking the Sociological Imagination. Westport, CN: Greenwood Press.

Kellner, Douglas. 2005. "Salvaging Democracy after Election 2004." Fast Capitalism 1.2 www.fastcapitalism.com [on-line journal].

Kennedy, John F. "Commencement Address at American University.” 10 June 1963. http://www.jfklibrary.org/j061063. htm.

Lifton, David S. 1980. Best Evidence: Disguise and Deception in the Assassination of John F. Kennedy. New York: Macmillan.

Mailer, Norman. 1995. Oswald's Tale: An American Mystery. New York: Random House.

Marcuse, Herbert. 1969 [1937]. "The Affirmative Character of Culture," in Negations, edited and translated by Jeremy J. Shapiro. Boston: Beacon Press.

1964. One-Dimensional Man. Boston: Beacon Press.

Michels, Robert. 1966 [1911]. Political Parties. New York: Free Press.

Mills, C. Wright. 2000 [1956]. The Power Elite. Oxford: Oxford University Press. New Edition, With Afterword by Alan Wolfe. . 1962. The Marxists. New York: Dell Publishing.

. 1960a. "Letter to the New Left," in Power, Politics, People:

The Collected Essays of C. Wright Mills, edited and with an Introduction by Irving Louis Horowitz. Oxford: Oxford University Press. Pp. 247-259.

.1960b. Images of Man: The Classic Tradition in Sociological Thinking, selected and edited with an introduction by C. Wright Mills. New York: George Braziller, Inc.
. 1959. The Sociological Imagination. Oxford: Oxford

University Press. . 1958. The Causes of World War Three. Westport, CN: Greenwood Press.

. 1951. White Collar. Oxford: Oxford University Press.

. 1946. From Max Weber: Essays in Sociology, translated and edited with Hans H. Gerth.

Mills, Kathryn, ed., with Mills, Pamela. 2000. C. Wright Mills: Letters and Autobiographical Writings, with an introduction by Dan Wakefield. Berkeley: University of California Press.

Oakes, Guy, and Vidich, Arthur. 1999. Collaboration, Reputation, and Ethics in American Academic Life: Hans H. Gerth and C. Wright Mills. Urbana: University of Illinois Press.

Orwell, George. 1983 [1949]. Nineteen Eighty-Four. New York: The New American Library.

Pinter, Harold. "Nobel Lecture." 7 December 2005. http://nobelprize.org/literature/laureates/2005/pinter-lecture.html.

Ryan, William. 1976. Blaming the Victim. Revised and Expanded Edition. New York: Vintage.

Sick, Gary. 1991. The October Surprise. New York: Three Rivers Press.

Silverman, H. J., ed. 1970. American Radical Thought: The Libertarian Tradition. Lexington, MA: D.C. Heath and Company.

Stinnett, Robert. 2001. Day of Deceit: The Truth About FDR and Pearl Harbor. New York: Free Press.

Tillman, Rick. 2004. Thorstein Veblen, John Dewey, C. Wright Mills and the Generic Ends of Life. New York: Rowman \& Littlefield.

1984. C. Wright Mills: A Native Radical and His American Intellectual Roots. University Park, PA: Pennsylvania State University Press.

Wakefield, Dan. 2000. Introduction, in C. Wright Mills: Letters and Autobiographical Writings, edited by Kathryn Mills (with Pamela Mills). Berkeley: University of California Press. Pp. $1-18$. Griffen.

1999. New York in the 50's. New York: St. Martin's

Wills, Gary. 1970. Nixon Agonistes: The Crisis of the Self-Made Man. New York: Mariner Books.

Wolfe, Alan. 2000. Afterword. In The Power Elite by C. Wright Mills, New Edition. Oxford: Oxford University Press. Pp. 363-381.

1989. Whose Keeper?: Social Science and Moral Obligation. Berkeley: University of California Press.

Zinn, Howard. 1990 [1970]. "What is Radical History?" In The Politics of History. Second Edition. Urbana: University of Illinois Press. Pp. 35-55. 
